\title{
Seasonal methane accumulation and release from a gas emission site in the central North Sea
}

\author{
S. Mau ${ }^{1}$, T. Gentz ${ }^{2}$, J.-H. Körber ${ }^{1}$, M. E. Torres ${ }^{3}$, M. Römer ${ }^{1}$, H. Sahling ${ }^{1}$, P. Wintersteller ${ }^{1}$, R. Martinez ${ }^{2}$, \\ M. Schlüter ${ }^{2}$, and E. Helmke ${ }^{2}$ \\ ${ }^{1}$ MARUM - Center for Marine Environmental Sciences and Department of Geosciences, University of Bremen, \\ Klagenfurter Str., 28359 Bremen, Germany \\ ${ }^{2}$ Alfred Wegener Institute, Helmholtz Centre for Polar and Marine Research, Am Handelshafen 12 , \\ 27570 Bremerhaven, Germany \\ ${ }^{3}$ College of Oceanic and Atmospheric Sciences, Oregon State University, 104 Ocean Admin Building, Corvallis, \\ Oregon 97331-5503, USA
}

Correspondence to: S. Mau (smau@marum.de)

Received: 10 October 2014 - Published in Biogeosciences Discuss.: 19 December 2014

Revised: 28 July 2015 - Accepted: 1 August 2015 - Published: 16 September 2015

\begin{abstract}
We investigated dissolved methane distributions along a $6 \mathrm{~km}$ transect crossing active seep sites at $40 \mathrm{~m}$ water depth in the central North Sea. These investigations were done under conditions of thermal stratification in summer (July 2013) and homogenous water column in winter (January 2014). Dissolved methane accumulated below the seasonal thermocline in summer with a median concentration of $390 \mathrm{nM}$, whereas during winter, methane concentrations were typically much lower (median concentration of $22 \mathrm{nM}$ ). High-resolution methane analysis using an underwater massspectrometer confirmed our summer results and was used to document prevailing stratification over the tidal cycle. We contrast estimates of methane oxidation rates (from 0.1 to $4.0 \mathrm{nM} \mathrm{day}{ }^{-1}$ ) using the traditional approach scaled to methane concentrations with microbial turnover time values and suggest that the scaling to concentration may obscure the ecosystem microbial activity when comparing systems with different methane concentrations. Our measured and averaged rate constants $\left(k^{\prime}\right)$ were on the order of 0.01 day $^{-1}$, equivalent to a turnover time of 100 days, even when summer stratification led to enhanced methane concentrations in the bottom water. Consistent with these observations, we could not detect known methanotrophs and pmoA genes in water samples collected during both seasons. Estimated methane fluxes indicate that horizontal transport is the dominant process dispersing the methane plume. During periods of high wind speed (winter), more methane is lost to the atmosphere
\end{abstract}

than oxidized in the water. Microbial oxidation seems of minor importance throughout the year.

\section{Introduction}

Methane is, after water vapor and $\mathrm{CO}_{2}$, the most important greenhouse gas. Its concentration has increased by a factor of 2.5 since preindustrial times, from $722 \mathrm{ppb}$ in 1750 to $1800 \mathrm{ppb}$ in 2011 (IPCC, 2013). The total global emission has been estimated to be $\sim 550 \mathrm{Tg}$ (methane) $\mathrm{yr}^{-1}$ with an anthropogenic contribution of 50 to $65 \%$. Geological sources, which were not considered in IPCC reports previously, are suggested to account for up to $30 \%$ of total emissions. These include anthropogenic emissions related to leaks in the fossil fuel industry, as well as natural geological seeps both terrestrial and marine (IPCC, 2013). An improved emission estimate from marine seeps suggests that these sources contribute $\sim 20 \mathrm{Tg}$ methane $\mathrm{yr}^{-1}$, i.e., $4 \%$ of the global emissions, to the atmospheric methane (Etiope et al., 2008).

In general, oceans are a minor source of methane to the atmosphere, accounting for $2-10 \%$ of the global emissions (Bange et al., 1994). The main oceanic source $(75 \%)$ is thought to originate from estuarine, shelf, and coastal areas (Bange, 2006; Bange et al., 1994). The European coastal areas were found to emit $0.46-1 \mathrm{Tg} \mathrm{yr}^{-1}$, but this value may 
underestimate the coastal input, since fluxes from estuaries and shallow seeps have not been represented adequately (Bange, 2006).

Although continental margins account for only $10 \%$ of the total ocean area and $20 \%$ of the marine primary production (Killops and Killops, 1993), more than $90 \%$ of all organic carbon burial occurs in sediment deposits on deltas, continental shelves, and upper continental slopes (Berner, 1989). At these locations, which are also characterized by high sedimentation rates, organic carbon is rapidly buried beneath the sulfate reduction zone and becomes available to methanogens (e.g., Cicerone and Oremland, 1988). Methane is also generated by thermal breakdown at high temperature and pressure. A significant fraction of the methane is oxidized in anaerobic and aerobic sediments (e.g., Boetius et al., 2000; Jørgensen and Kasten, 2006; King, 1992; Niewöhner et al., 1998). At cold seep sites, methane escaping microbial oxidation may be transported into the overlying water either dissolved in upwardly advecting pore waters or, in case of oversaturation, in the form of gas bubbles. Because methane is undersaturated in seawater, rising methane bubbles partially dissolve during ascent through the water column (McGinnis et al., 2006), where the dissolved methane may be further consumed by microbial oxidation. Only if this methane survives transport to the mixed layer may it be transferred to the atmosphere.

Because of processes consuming methane in the water column, shallow seeps are more likely to contribute to the atmospheric methane pool. However, even at shallow sites, density stratification may limit vertical transport. For example, at the $70 \mathrm{~m}$ deep Tommeliten area in the North Sea, a summer thermocline constrains methane transport to the atmosphere and numerical modeling showed that during this season less than $\sim 4 \%$ of the gas initially released at the seafloor reaches the mixed layer (Schneider von Deimling et al., 2011). Here we examine the seasonal cycle of methane in the North Sea by chemical and microbiological analyses of water samples collected in a region of shallow seepage during summer (July 2013) and winter (January 2014). For the case of expected seasonal stratification, we further consider whether the methane trapped in bottom waters is significantly consumed by microbial oxidation during summer, thus limiting the fraction that can be released at the onset of storm events in fall.

\subsection{Study site}

The study site is situated in an area of active gas venting above a shallow gas reservoir in the central North Sea south of Dogger Bank, a sandbank that is $20 \mathrm{~m}$ shallower than the surrounding seabed (Fig. 1). The gas vents are located in the Netherlands sector, license block B13 in a shallow $(<45 \mathrm{~m})$ and flat region that lacks any morphological expression typical of seep structures (Schroot et al., 2005). The seeps are likely sourced from a biogenic methane reservoir $\left(\delta^{13} \mathrm{C}\right.$ val-

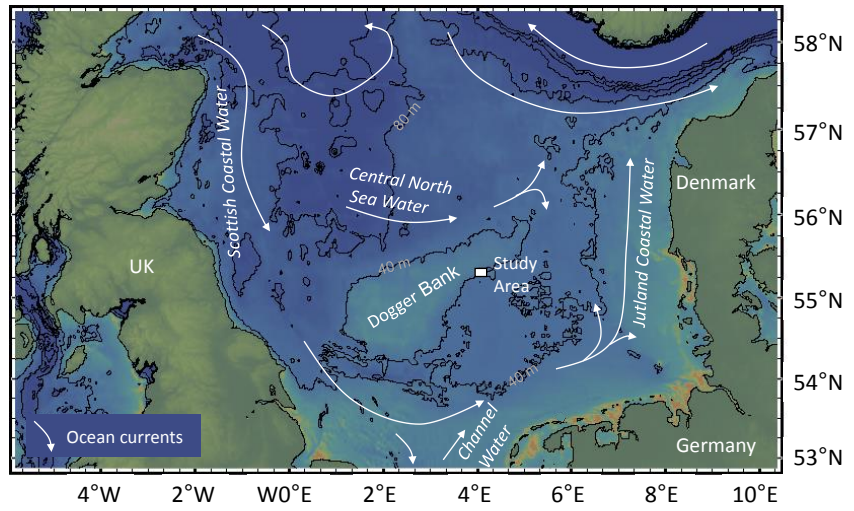

Figure 1. Location of the study area in the central North Sea. The main currents are shown following Howarth (2001). The map was drawn using GeoMapApp with $40 \mathrm{~m}$ contours.

ues of $-80 \%$ VPDB) of Pliocene to Pleistocene age, which lies 600-700 m below the seafloor. Schroot et al. (2005) imaged patches of gas-saturated sediments between the gas reservoir and the seafloor in seismic surveys. These data, plus observations of distinct bubble streams in the water column and rapidly decreasing methane concentrations in cores with distance from the vent site, led Schroot et al. (2005) to describe our study area as a leaking gas reservoir with laterally discontinuous seepage.

In this region, water masses from the north (Atlantic Water) and south (Straits of Dover) meet (Kröncke and Knust, 1995) and the general anticlockwise circulation along the coasts of the North Sea becomes weak and varied (Fig. 1, Howarth, 2001). Tides have the strongest influence on the currents in this region, with wind forcing becoming secondary (Howarth, 2001; Otto et al., 1990; Sündermann and Pohlmann, 2011).

Seasonal temperature stratification, common to this and other shelf seas, separates high-light and low-nutrient surface water from low-light and high-nutrient bottom water. Even though in some shelf areas, the tidal energy is sufficient to overcome stratification, Pingree and Griffiths (1978) and Holt and Umlauf (2008) have shown that our study area is situated east of the tidal front that bifurcates Dogger bank. Consequently, the water column above the Dogger sandbank is well mixed throughout the year, whereas the deeper waters that surround the bank become stratified during spring and summer through the course of a tidal cycle.

\section{Methods}

All data used in this study were collected during two cruises with RV Heincke. The first cruise (HE406) was conducted during summer 2013 (20-24 July) and the second cruise (HE413) during winter 2014 (13-22 January). 


\subsection{EM710 flare imaging}

Hydroacoustic data were collected only during the winter cruise, using a Kongsberg EM710 multibeam echosounder to map active gas emissions (Fig. 2). For the precise localization of individual flares, i.e., bubble streams in an echogram, the water column data were post-processed using the Fledermaus tools FMMidwater, DMagic, and the 3D Editor $\left({ }^{\circledR} \mathrm{QPS}\right)$. The origin of individual flares was identified as the point of highest amplitudes near the seafloor. The coordinates of these points were extracted using the FMGeopicker and subsequently plotted on top of the bathymetry using ArcGIS 10.2 ( ${ }^{\circledR}$ ESRI).

For visualization of flare deflections and bubble rising heights, selected flares were extracted from the water column data as point data and edited using the 3D Editor of DMagic. The processed flares were plotted over the bathymetry data in a $3 \mathrm{D}$ view (Fig. 2).

\subsection{Water column sampling}

To identify the size and magnitude of the dissolved methane plume generated by the bubble discharge, seawater was sampled along a hydrocast transect that crossed the active gas emission sites (Fig. 2). The transect extends $3 \mathrm{~km}$ to the east and $3 \mathrm{~km}$ to the west from the main bubbling location denoted as cluster 1 in Fig. $2 \mathrm{a}$ and c $\left(4^{\circ} 5.44^{\prime} \mathrm{N}, 55^{\circ} 18.36^{\prime} \mathrm{E}\right)$. To better capture the methane plumes and minimize tidal current changes, the station transect was oriented in the direction of the dominant east-west tidal water movement. The stations were sampled both in summer 2013 and in winter 2014; in both cases, the eastern sector (five stations) was sampled on 1 day ( $\sim 3 \mathrm{~h}$ ) and the western sector (five stations) on another day $(\sim 3 \mathrm{~h})$, so that the station directly above cluster 1 was sampled twice.

We used a rosette equipped with $125 \mathrm{~L}$ Niskin bottles mounted on a frame that holds a Sea-Bird SBE 911 plus conductivity, temperature, and depth (CTD) sensors and an SBE 43 oxygen sensor for online monitoring of salinity, temperature, pressure, and dissolved oxygen. The data are archived in PANGAEA (doi:10.1594/PANGAEA.824863 and doi:10.1594/PANGAEA.832334). Twelve different water depths were sampled at each station for quantification of the methane concentration and five water depths for methane oxidation rates. Additional casts were conducted to recover sufficient water for molecular analyses.

\subsubsection{Methane concentration}

For methane concentration analysis, samples were collected in $60 \mathrm{~mL}$ crimp-top glass bottles, flushed with 2 volumes of sample water and filled completely to eliminate bubbles. Bottles were immediately capped with butyl rubber stoppers and crimp sealed. After adding $0.2 \mathrm{~mL}$ of $10 \mathrm{M} \mathrm{NaOH}$ to stop any microbial activity, a $5 \mathrm{~mL}$ headspace of pure $\mathrm{N}_{2}$ was intro- duced into each bottle as described in Valentine et al. (2001) and the samples were stored at $4{ }^{\circ} \mathrm{C}$. One to two aliquots of the headspace were analyzed to determine methane concentrations using a gas-phase chromatograph equipped with a flame ionization detector. The methane concentrations were calculated as detailed in Magen et al. (2014). Analyses were performed both on board and post-cruise. Replicate analyses of samples yielded a precision of $\pm 5 \%$.

\subsubsection{Methane oxidation rates}

Methane oxidation (MOx) rates were determined from ex situ incubations of water samples in $100 \mathrm{~mL}$ serum vials. Sample collection and incubation were performed as described in Mau et al. (2013). Briefly, duplicate samples were collected and $50 \mu \mathrm{L}$ of ${ }^{3} \mathrm{H}$-labeled methane $(160-210 \mathrm{kBq})$ in $\mathrm{N}_{2}$ were added to each sample. After shaking the bottles to equilibrate the tracer with the water, the samples were incubated in the dark for $24 \mathrm{~h}$; those collected in summer 2013 were incubated at $10^{\circ} \mathrm{C}$ and those from winter 2014 at $9{ }^{\circ} \mathrm{C}$. After incubation, the total activity $\left({ }^{3} \mathrm{H}-\mathrm{CH}_{4}+{ }^{3} \mathrm{H}-\mathrm{H}_{2} \mathrm{O}\right)$ in an $1 \mathrm{~mL}$ aliquot was measured by wet scintillation counting; the activity of ${ }^{3} \mathrm{H}-\mathrm{H}_{2} \mathrm{O}$ was measured after sparging the sample for $>30$ min with $\mathrm{N}_{2}$ to remove excess ${ }^{3} \mathrm{H}-\mathrm{CH}_{4}$, so that the net amount of ${ }^{3} \mathrm{H}-\mathrm{CH}_{4}$ consumption can be estimated. The precision of the analysis was better than $5 \%$. Analyses of replicate samples yield values that differ by up to $30 \%$.

MOx rates were calculated assuming first-order kinetics (Reeburgh et al., 1991; Valentine et al., 2001):

$\mathrm{MOx}=k^{\prime}\left[\mathrm{CH}_{4}\right]$,

where $k^{\prime}$ is the effective first-order rate constant calculated as the fraction of labeled methane oxidized per unit time, and $\left[\mathrm{CH}_{4}\right]$ is the in situ methane concentration. To verify first-order kinetics we conducted time series incubations and measured the tracer consumption after 1, 2, 3, and 4 days. The MOx values were corrected for differences between in situ and incubation temperatures (Supplement 1).

In addition, control samples were frequently taken and poisoned immediately after the addition of the tracer. The mean $(\bar{x})$ and standard deviation (SD) of all controls sampled during a cruise were calculated and the limit of detection (LOD) was set as

$\mathrm{LOD}=\bar{x}+3 S D$.

The LOD was 0.02 and $0.09 \mathrm{nM}$ day $^{-1}$ for the summer 2013 and winter 2014 surveys, respectively.

\subsubsection{Analysis of bacterial communities}

The composition of the bacterioplankton assemblages was examined using denaturing gradient gel electrophoresis (DGGE) based on the 16S rRNA gene as described in Mau et al. (2013). In short, immediately after sampling, $8 \mathrm{~L}$ of water were filtered and the bacterial cells were concentrated on 


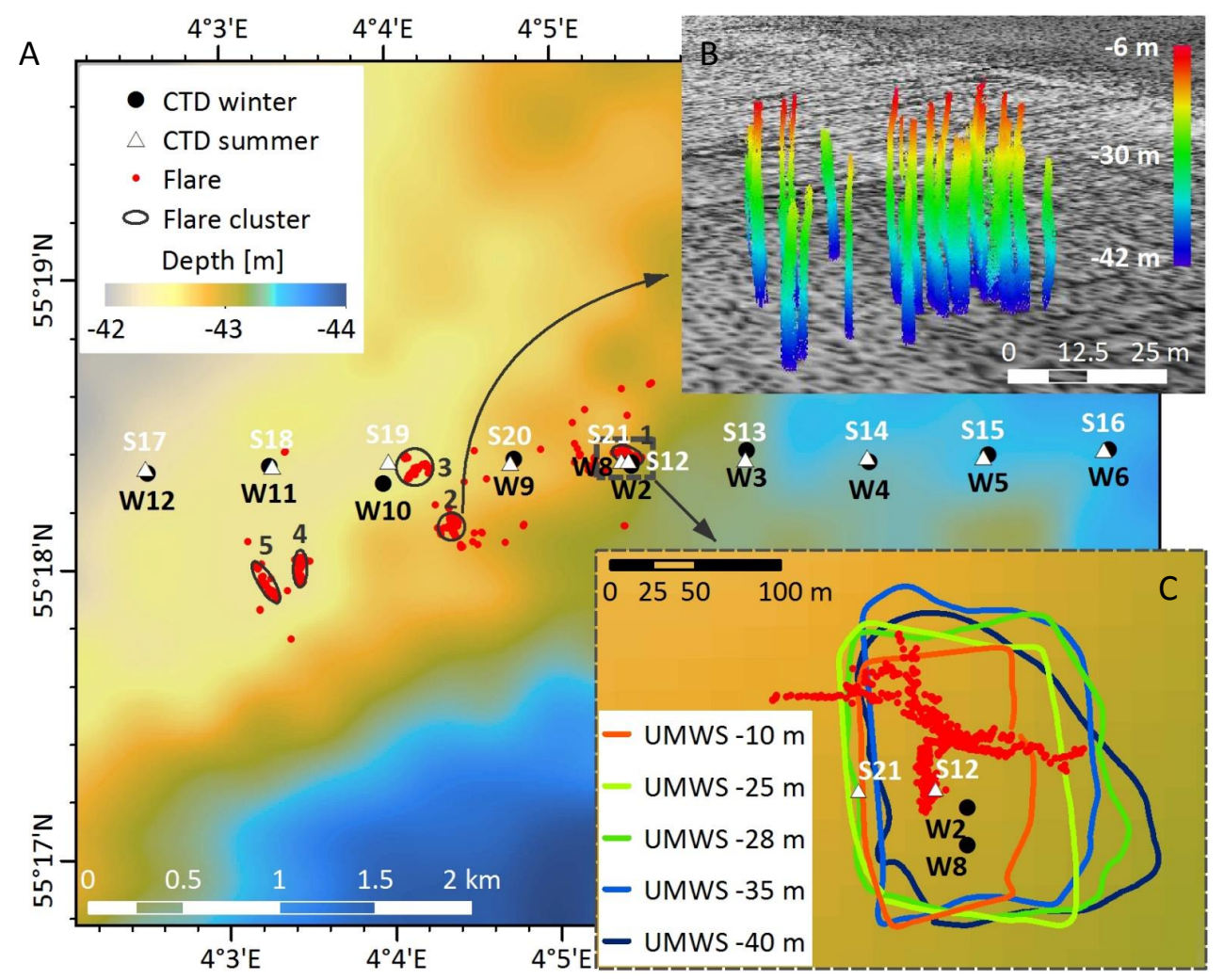

Figure 2. (a) Overview of gas flares mapped in January 2014 and CTD stations sampled in July 2013 (S12-S21) and January 2014 (W2W12). Flares cluster in five distinct areas (clusters 1-5) and reach to $6 \mathrm{~m}$ from the sea surface (e.g., cluster 2, b), which corresponds to the echosounder's transducer depth. Hence, most likely the gas transport extends to the sea surface. Cluster 1 corresponds to the gas seep area investigated by Gentz (2013) (c).

Nuclepore filters $(0.2 \mu \mathrm{m}$ pore size $)$. The filters were stored on board at -20 and at $-80^{\circ} \mathrm{C}$ post-cruise. DNA was extracted by an UltraClean Soil DNA Kit (MoBio Laboratories, USA). A 16S-rRNA-gene-specific polymerase chain reaction (PCR) was conducted using the forward primer GM5 plus GC clamp and the reverse primer 907RM (Muyzer et al., 1993) under conditions described by Gerdes et al. (2005). The PCR products (ca. 500 bp) were analyzed by DGGE according to the protocol of Muyzer et al. (1993). Clearly visible bands of the DGGE gels were excised from the gel. The DNA was reamplified by PCR (Gerdes et al., 2005) and sequenced. The 16S rRNA gene sequences were taxonomically assigned by SILVA Online Aligner (Pruesse et al., 2012).

The presence of methane-oxidizing bacteria was checked by searching for genes encoding the particulate methane monooxygenase ( $p m o A)$, a key enzyme of methanotrophs (McDonald et al., 2008). The pmoA-gene-specific PCR reaction was conducted by using the primer set " $p m o A$ " and amplification conditions described in McDonald and Murrell (1997).

\subsection{Methane concentration analysis by underwater mass spectrometry (UWMS)}

In addition to the conventional methane analysis, in situ methane concentrations were quantified with an UWMS during the summer 2013 cruise (Inspectr200-200, Bell et al., 2007; Gentz et al., 2013; Schlüter and Gentz, 2008; Short et al., 2001; Wenner et al., 2004). The fast sampling frequency $(\leq 2 \mathrm{~s})$ of the UWMS allows mapping of methane concentrations at much higher resolution than the commonly used CTD/rosette-sampling technique. The instrument consists of a membrane inlet system (MIS), an Inficon (Bad Ragaz, Switzerland) Transpector CPM 200 quadruple mass spectrometer, a Varian (Palo Alto, USA) turbo pump, a roughing pump, a peristaltic pump (KC Denmark), an embedded PC, and a microcontroller. The UWMS was partly redesigned to include a cooling system (Ricor, K508), which lowers the detection limit for methane to $16 \mathrm{nM}$. The cooling system and the improvement of the detection limit are described in detail by Gentz and Schlüter (2012) and Schlüter and Gentz (2008). For reproducible gas permeation through the MIS, water is constantly heated to a steady temperature of 
$50^{\circ} \mathrm{C}$ and pumped at a flow rate of $3 \mathrm{~mL} \mathrm{~min}^{-1}$ along the membrane by an external peristaltic pump.

The UWMS was deployed above the central gas seeps (cluster 1, Fig. 2) on 21 July 2013 (16:31-22:32 UTC) at five different water depths: just above the seafloor, 35, 28, 25 , and $10 \mathrm{~m}$. When the system had reached the respective depth, the research vessel moved slowly along a rectangular track $(\sim 125 \mathrm{~m} \mathrm{~S}-\mathrm{N}, \sim 150 \mathrm{~m} \mathrm{E}-\mathrm{W}$, Fig. $2 \mathrm{c})$ surrounding the flares of cluster 1 and towed the UWMS, which continuously measured the methane concentrations. Each of the five tows (Fig. 2c) took approximately $1 \mathrm{~h}$ and recorded 400-800 methane concentration values.

\subsection{Estimation of methane fluxes}

Advection, horizontal and vertical turbulent diffusion, seaair flux, and microbial oxidation rates were quantified for the upper $(0-30 \mathrm{~m})$ and lower water column $(30-40 \mathrm{~m})$ during summer stratification (July 2013) and for the entirely mixed water column (0-40 m) in winter (January 2014).

The advective flux (ADV) was calculated by multiplying methane concentration $\left(\left[\mathrm{CH}_{4}\right]\right)$ and current velocity $(v)$ :

$\mathrm{ADV}=v\left[\mathrm{CH}_{4}\right]$.

Methane concentrations were averaged above and below the thermocline from the summer survey, and averages throughout the water column were calculated from the winter data. Current velocities refer to the resultant velocities calculated from the $u$ and $v$ component of the velocity vectors (Supplements 2 and 3 ) and were averaged over the time period of sampling. The current data provided by the Bundesamt für Seeschifffahrt und Hydrographie (BSH) (www.bsh.de/de/ Meeresdaten/Vorhersagen/Vorhersagemodelle/index.jsp) are based on wind and air temperature forecasts. Such modeled data have been validated by a few current measurements and have an uncertainty of $\sim 10 \%$. Together with the uncertainty of the methane concentration, the estimated advective flux has an uncertainty of $\sim 15 \%$.

If advective transport were to be uniform then it would simply displace methane, but differences in current velocity and direction with depth lead to turbulent mixing, i.e., eddy diffusion (DIF). The strength of small-scale motions that act to smooth out concentration gradients can be parameterized by the eddy diffusivity $\kappa$, such that mass transport is proportional to the mean concentration gradient (Largier, 2003; Roberts and Webster, 2002):

$\mathrm{DIF}=\kappa\left(\frac{\partial\left[\mathrm{CH}_{4}\right]}{\partial x}\right)$

where $\kappa$ is the horizontal or vertical diffusion coefficient in $\mathrm{m}^{2} \mathrm{~s}^{-1} . \delta\left[\mathrm{CH}_{4}\right] / \delta x$ is the spatial concentration gradient in $\mathrm{nM} \mathrm{m}^{-1}$, estimated between the center and the outermost stations in the case of horizontal diffusion calculation, and the concentration gradient between the lower and upper water column in the case of vertical diffusion (Mau et al., 2012), calculated only for summer 2013.

$\kappa_{y}$, the horizontal diffusion coefficient, can range between 0.1 and $1000 \mathrm{~m}^{2} \mathrm{~s}^{-1}$ (Largier, 2003; Sundermeyer and Price, $1998)$ depending on the proximity to land. $\kappa_{y}$ exponentially increases with distance from the shore: $\kappa_{y}$ is on the order of $1-10 \mathrm{~m}^{2} \mathrm{~s}^{-1}$ if $y \sim 0.1 \mathrm{~km}, \sim 100 \mathrm{~m}^{2} \mathrm{~s}^{-1}$ if $y \sim 10 \mathrm{~km}$, and $1000 \mathrm{~m}^{2} \mathrm{~s}^{-1}$ or greater if $y \sim 100-1000 \mathrm{~km}$. As the study area is located more than $230 \mathrm{~km}$ from shore, we used a $\kappa_{y}$ of $1000 \mathrm{~m}^{2} \mathrm{~s}^{-1}$ for our calculations. The vertical turbulent diffusion coefficient $\left(\kappa_{z}\right)$ can vary between $10^{-3}$ and $10^{-6} \mathrm{~m}^{2} \mathrm{~s}^{-1}$ depending on the energy in the water column (wind, tides, etc.) and stratification (Denman and Gargett, 1983; Wunsch and Ferrari, 2004). $\kappa_{z}$ was estimated according to the equation by Osborn (1980):

$\kappa_{z}=\Gamma \frac{\epsilon}{\mathrm{N}^{2}}$,

where $\Gamma$ is the efficiency of mixing and assumed to be a constant of 0.2. We used published dissipation rates of turbulent kinetic energy $(\epsilon)$ in stratified shallow shelf seas (Palmer et al., 2008; Thorpe et al., 2008) and calculated the buoyancy frequency $(\mathrm{N})$ from the available CTD profiles. The results indicate that $\kappa_{z}$ is on the order of $10^{-4}$ to $10^{-6} \mathrm{~m}^{2} \mathrm{~s}^{-1}$ during stratification. This rough approximation neglects hourly changes, which can vary by an order of magnitude. For example, Palmer et al. (2008) observed and calculated $\kappa_{z}$ to range between $10^{-4}$ and $10^{-5} \mathrm{~m}^{2} \mathrm{~s}^{-1}$ over a tidal cycle. We used $10^{-4} \mathrm{~m}^{2} \mathrm{~s}^{-1}$, which is a common cited value across the thermocline, in order to not underestimate the vertical eddy diffusion. These diffusion fluxes were estimated for all vertical profiles (all 10 CTD stations). The uncertainty of these estimates is determined by that of the diffusion coefficient, which can vary by an order of magnitude.

The sea-air flux (SAF) was calculated as

$\mathrm{SAF}=k_{\mathrm{W}}\left(\left[\mathrm{CH}_{4}\right]_{\mathrm{W}}-\left[\mathrm{CH}_{4}\right]_{\mathrm{A}}\right)$,

where $k_{\mathrm{W}}$ is the gas transfer velocity in $\mathrm{cm} \mathrm{h}^{-1},\left[\mathrm{CH}_{4}\right]_{\mathrm{W}}$ is the measured concentration of methane, and $\left[\mathrm{CH}_{4}\right]_{\mathrm{A}}$ is the methane concentration in atmospheric equilibrium, both in $\mathrm{nM}$. We calculated $k_{\mathrm{W}}$, which depends on wind speed and the temperature-dependent Schmidt number of the gas, using parameterization developed by McGillis et al. (2001). Mau et al. (2007) show that error associated with $k_{\mathrm{W}}$ estimates can yield a flux uncertainty of $10-40 \%$. Wind speed was recorded $22 \mathrm{~m}$ above sea level on board with a precision of $20 \%$ and corrected to the standard height of $10 \mathrm{~m}$. $\left[\mathrm{CH}_{4}\right]_{\mathrm{A}}$ was derived using the mean atmospheric methane concentration of Ocean Station M, Norway, at $66^{\circ} \mathrm{N}$ and $2^{\circ} \mathrm{E}$ in 2009 (1.874 ppm, http://www.esrl.noaa.gov/gmd/dv/ data/), the Bunsen solubilities given by Wiesenburg and Guinasso (1979) and measured ocean temperature and salinities. The sea-air flux was calculated for surface water samples of all 10 stations sampled in summer 2013 and winter 2014. As the sea-air flux depends strongly on wind speed, 
the crucial uncertainties of this flux are associated with wind speed measurements and the parameterizations of the gas transfer velocity, which yield an overall uncertainty of less than an order of magnitude.

The oxidative loss (OL) was calculated by depth integration of the $\mathrm{MOx}$ rates:

$\mathrm{OL}=\bar{x}_{\mathrm{MOx}} z$

where $\bar{x}_{\text {MOx }}$ is the averaged MOx rate in $\mathrm{nM} \mathrm{day}^{-1}$ over the depth interval $z$ in meters. The depth interval is defined by the water stratification in the case of summer 2013 and covers the entire water depth in the case of winter 2014. Integration was done for all vertical profiles. The estimated oxidative loss of methane varies by $<30 \%$ according to the precision of the oxidation rate measurement.

\section{Results}

\subsection{Seep locations}

Echosounder data collected during the winter survey indicate bubble emission in the area of the sampled transect (Fig. 2). The center station was located at a known gas bubble emission site or flare cluster, where several bubble streams occur in close proximity to each other. We observed four additional flare clusters near the western sector of the transect, similar in seepage intensity as those from the central seep denoted as cluster 1 (Fig. 2a and c). In contrast, no additional flares were found in the area of the eastern sector. Although echosounder data point to bubbles rising to, or close to, the sea surface, no bubbles were visually identified at the sea surface due to the rough sea state. Seepage intensity showed no obvious variation related to tidal cycles, i.e., pressure variations due to high or low tides. The seeps were found to be active during all survey crossings. No echosounder data were collected in summer 2013; nonetheless, surfacing gas bubbles were visually documented when the sea was calm.

\subsection{Oceanographic setting}

In summer (July 2013) a seasonal thermocline separated surface $(0-30 \mathrm{~m})$ from bottom waters $(30-42 \mathrm{~m}$; Fig. 3$)$. The surface water consisted of a $10 \mathrm{~m}$ thick mixed layer below which the temperature decreased stepwise from 17.5 to $7^{\circ} \mathrm{C}$ in $30 \mathrm{~m}$. Lower salinity was observed at 15 and $25 \mathrm{~m}$ depths, which departed from the general value of 34.55. The stepwise decrease in temperature and the salinity variations indicate the successive development of several pycnoclines driven by increasing sea surface temperatures and steadily weakening wind activity in spring and summer. The oxygen concentrations increased from $220 \mu \mathrm{M}$ at the surface to $240 \mu \mathrm{M}$ at $30 \mathrm{~m}$. In contrast to the surface water, the bottom water had a homogeneous temperature of $7.18 \pm 0.09^{\circ} \mathrm{C}$, a salinity of $34.63 \pm 0.02$, and contained less oxygen $(190 \pm 5 \mu \mathrm{M})$.
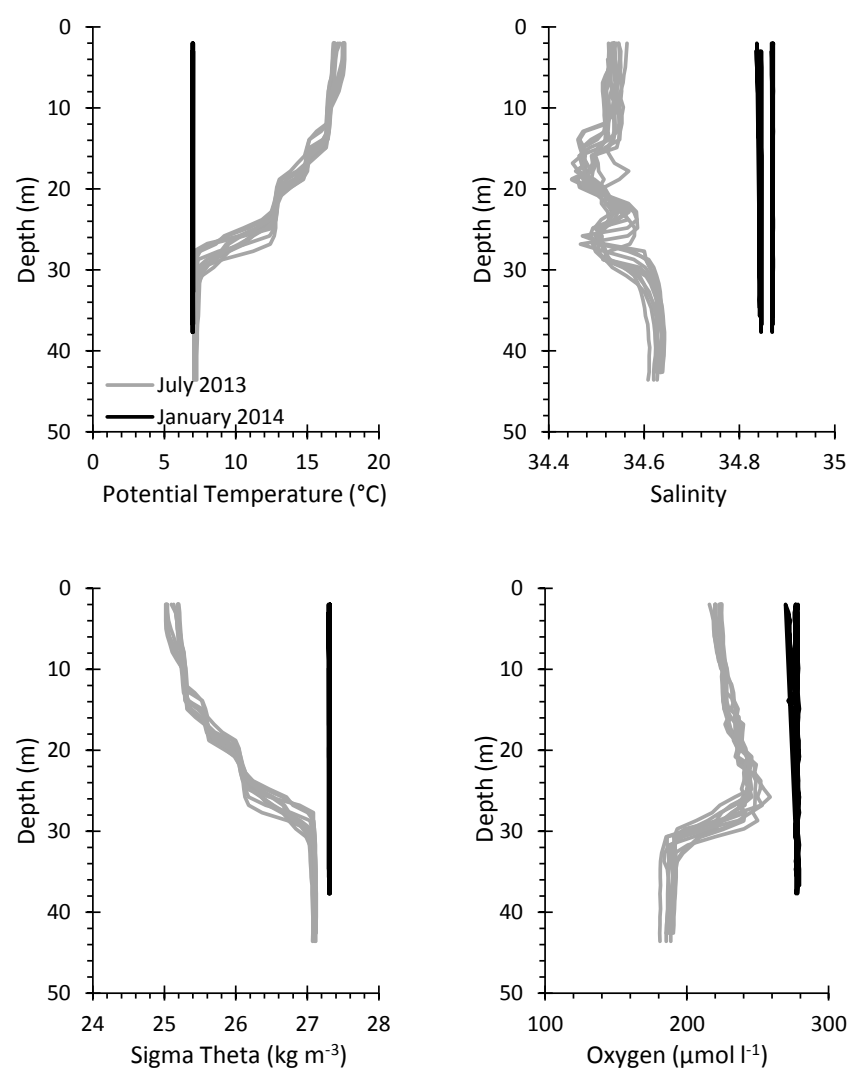

Figure 3. Depth profiles of potential temperature, salinity, density (sigma theta), and oxygen for all stations in both summer and winter field programs.

In winter (January 2014) the entire water column was mixed (Fig. 3). The water had a temperature of $7^{\circ} \mathrm{C}$, a salinity of 34.85 , a density of $27.3 \mathrm{~kg} \mathrm{~m}^{-3}$, and oxygen concentrations of $280 \mu \mathrm{M}$.

Modeled regional current data provided by the BSH indicate a dominant northwest transport throughout the water column with surface speeds ranging between 0.06 and $0.27 \mathrm{~m} \mathrm{~s}^{-1}$ (resultant speed). In summer, the eastern part of the transect was sampled when currents were directed to the northwest with an average speed of $0.24 \mathrm{~m} \mathrm{~s}^{-1}$ and the western part was sampled when currents turned from northwest to southwest with an average speed of $0.19 \mathrm{~m} \mathrm{~s}^{-1}$. In winter, the eastern part of the transect was sampled when water moved northeast turning northwest with an average speed of $0.22 \mathrm{~m} \mathrm{~s}^{-1}$, and the western part was also sampled when water turned from northeast to northwest but with an average speed of $0.1 \mathrm{~m} \mathrm{~s}^{-1}$. Water speed and direction plots are given in Supplements 2 and 3.

\subsection{Methane concentrations}

Consistent with the two-layer structure observed on the hydrographic data, the methane concentration in summer 2013 also show a two-layer distribution, with higher values in the 
bottom water (Fig. 4a, Supplement 4). Methane concentrations in the surface water range from 4 to $518 \mathrm{nM}$ with a median of $33 \mathrm{nM}$. Methane concentrations in the bottom water range between 40 and $1628 \mathrm{nM}$ with a median of $391 \mathrm{nM}$. Highest concentrations in the surface water were found near cluster $1(170 \mathrm{nM})$ and generally decreased towards the outermost stations (to the west to $96 \mathrm{nM}$ and to the east to $13 \mathrm{nM}$ ). Similarly, in the bottom water the highest methane concentrations were found at cluster 1 (600-700 nM), and concentrations decreased unevenly towards the outmost stations (200-300 nM). In both layers the methane concentrations exceeded the background concentration of $\sim 20 \mathrm{nM}$ as measured at a reference station located $32 \mathrm{~km}$ to the southeast of cluster 1 (Supplement 5) and of $20 \mathrm{nM}$ as reported by Grunwald et al. (2009). Even this regional background value is supersaturated with respect to the atmospheric equilibrium concentration of 2.3-2.9 nM (at the relevant $T / S$ conditions; Wiesenburg and Guinasso, 1979).

Much lower methane concentrations were found in winter 2014 (Fig. 4b, Supplement 4). Highest values were observed only at one station near cluster 1 with concentrations reaching $657 \mathrm{nM}$. Such elevated values decreased rapidly horizontally (within $1 \mathrm{~km}$ ) and were not encountered during repeated hydrocasts at the same location. The median of all methane concentration measurements along the transect was $22 \mathrm{nM}$, which is only slightly above the regional background concentration. In general, methane concentrations indicate a patchy spatial distribution as expected in an active seep area.

\subsection{UWMS methane concentrations}

The UWMS was deployed in the vicinity of flare cluster 1 in summer 2013, covering an area of $125 \mathrm{~m}$ by $150 \mathrm{~m}$ during instrument tow (Fig. 2c). Therefore, the hydrocast data (described in Sect. 3.3) cover a much larger spatial scale $(6 \mathrm{~km})$ than sampled during the UWMS tows. When the UWMS was towed close to bubble streams, it recorded methane concentrations that range over 3 orders of magnitude from $<16 \mathrm{nM}$ (the detection limit, which is recorded as 0) to $2127 \mathrm{nM}$ in surface waters (transects in 10, 25, and $28 \mathrm{~m}$ ). Values $>500 \mathrm{nM}$ only were recorded during a period of $\sim 11 \mathrm{~min}$ of the $\sim 30 \mathrm{~min}$ tow at $25 \mathrm{~m}$ and $\sim 4 \mathrm{~min}$ of the $\sim 60 \mathrm{~min}$ tow at $28 \mathrm{~m}$ (Fig. 5). During bottom transects (30 and $42 \mathrm{~m}$ ) methane concentration are generally higher and range from 259 to $2213 \mathrm{nM}$. The median values of the records from the 10,25 , and $28 \mathrm{~m}$ water depth tows were $<16,133$, and $158 \mathrm{nM}$, respectively, while the median in 30 and $40 \mathrm{~m}$ depth were 508 and $679 \mathrm{nM}$.

UWMS and hydrocasts were deployed during different tidal phases to check the persistence of higher methane concentrations in the bottom water as tidal pressure changes can affect methane seepage (Boles et al., 2001). The UWMS tows were conducted during ebbing tides, when water levels fell from 0.18 to $-0.27 \mathrm{~m}$, whereas hydrocast samples were collected during rising tides, when sea level height in- creased from -0.21 to $0.06 \mathrm{~m}$ and from 0.04 to $0.16 \mathrm{~m}$ (Supplement 6). The general pattern of lower concentrations in the surface and higher ones in the bottom water was apparent at all stations, even though methane data were obtained using different techniques and samples were collected during different tidal phases.

\subsection{Methane oxidation}

Similar to the distribution of methane and co-located oceanographic data, the MOx rates calculated using Eq. (1) show a two-layer pattern in summer 2013 but are uniform throughout the water column during the winter 2014 survey (Fig. 6a). In summer, MOx rates in surface waters ranged between 0.04 and $9.2 \mathrm{nM} \mathrm{day}^{-1}$ with a median of $0.1 \mathrm{nM} \mathrm{day}^{-1}$ and in the bottom water between 1.6 and $840.9 \mathrm{nM}^{-1}$ day $^{-1}$ with a median of $4.0 \mathrm{nM}$ day $^{-1}$. The total range of both layers $(0.04$ $840.9 \mathrm{nM} \mathrm{day}^{-1}$ ) exceeds the range of MOx rates observed during the winter survey $\left(0.1-8.7 \mathrm{nM}\right.$ day $\left.^{-1}\right)$. The median of all MOx rates measured in January 2014 was $0.2 \mathrm{nM}$ day $^{-1}$.

\subsection{Microbial communities}

Molecular samples taken in summer 2013 show also a difference between surface and deep waters, whereas winter 2014 samples indicate a homogeneous spatial distribution of microorganisms (Fig. 7, Table 1). In summer 2013, different DGGE banding patterns reveal changes in microbial communities with depth. The surface water samples showed two strong bands (Fig. 7, bands 6,7) that could be affiliated with the Rhodobacteraceae and two bands that could be assigned to the Cyanobacteria/Synechococcus clade $(8,9)$. The middle and bottom water samples were not only characterized by a strong chloroplast band (2) but also showed bands affiliated to the Rhodobacteraceae $(5,6)$. In the bottom water samples of the central station, we found an additional band, assigned to Pseudoalteromonas (10). The gel pattern of the winter samples showed no significant bands. The sequences of the faint bands excised were of low quality. Only two of the bands could be assigned to the Rhodospirillaceae (12, 13).

Neither the summer nor the winter bacterial communities exhibited known methanotrophic bacteria, even though the samples originate from an actively gas venting area. The absence of methanotrophic bacteria was further supported by the negative results of the $p m o A$ PCRs that target a methanotroph molecular marker gene.

\section{Discussion}

The echosounder and visual observations at the central North Sea sites document gas emissions that in some cases reach the sea surface. This fraction of methane that is transported directly to the atmosphere by bubbles and released upon bursting might be significant, as was shown for example at 


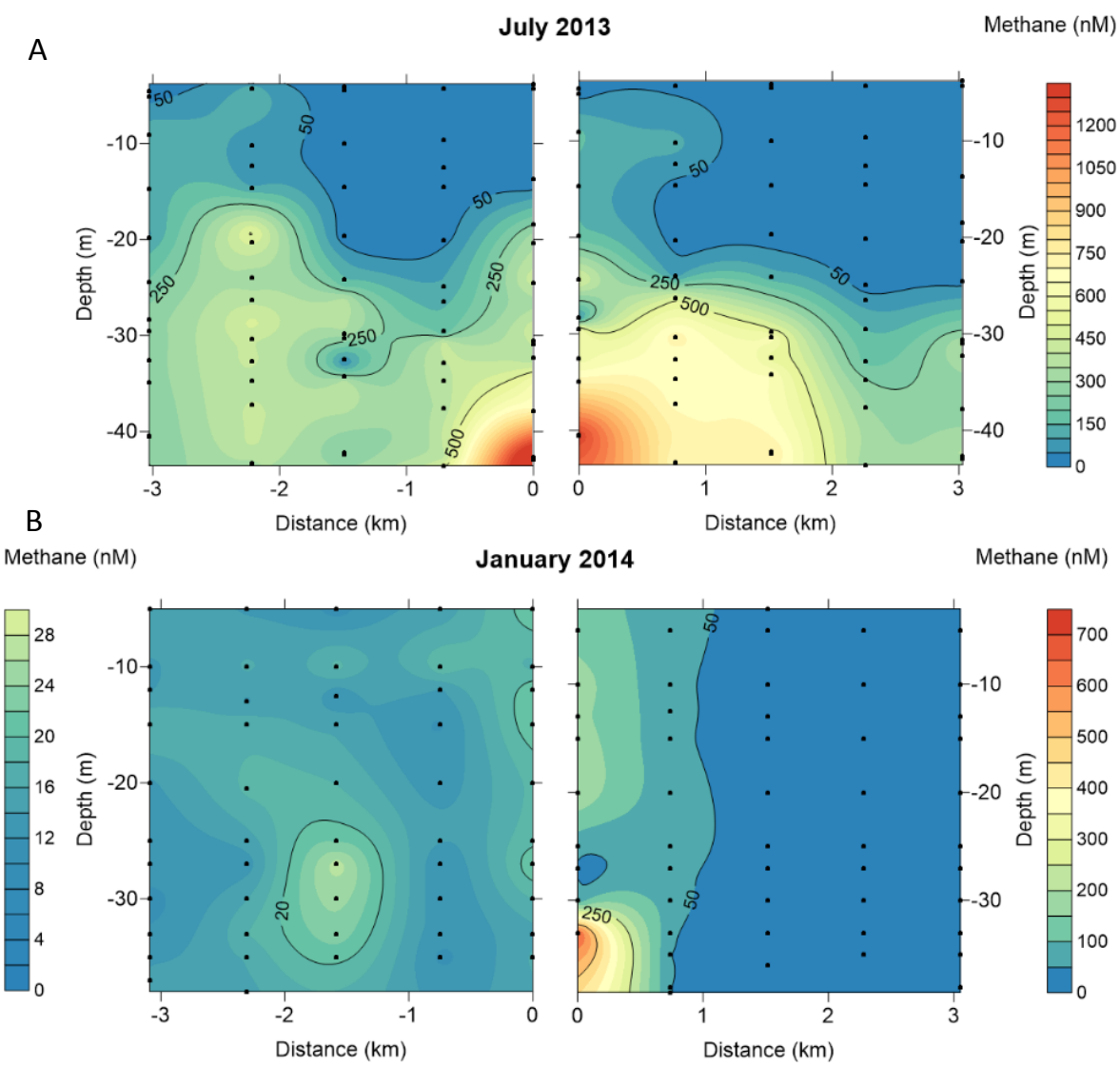

Figure 4. (a-b) Contour plots of the dissolved methane concentrations measured in the water column in July 2013 and January 2014 . The $6 \mathrm{~km}$ transect was divided into an eastern (positive numbers) and western part (negative numbers) starting from the center station at $0 \mathrm{~km}$. Note the different methane concentration scales, which are necessary to properly display the different concentration ranges. The black dots indicate the sampled water depths.

Table 1. Classification of partial 16S rRNA gene sequences (Fig. 7) to bacterial taxa performed with the SILVA classifier (Pruesse et al., 2012). The confidence value (0-1) for assignment at the level of class and genus is given in parentheses.

\begin{tabular}{lll}
\hline No. & Class & Family \\
\hline 1 & Alphaproteobacteria (0.4) & SARl1 clade (0.2) \\
2 & Cyanobacteria (1) & Chloroplast $(1)$ \\
3 & Alphaproteobacteria (1) & Rhodobacteraceae $(1)$ \\
4 & Bacteroidetes incertae sedis (0.43) & Marinifilum $(0.4)$ \\
5 & Alphaproteobacteria (1) & Rhodobacteraceae $(1)$ \\
6 & Alphaproteobacteria (1) & Rhodobacteraceae (1) \\
7 & Alphaproteobacteria (1) & Rhodobacteraceae $(1)$ \\
8 & Cyanobacteria (1) & Synechococcus $(1)$ \\
9 & Cyanobacteria (1) & Synechococcus $(1)$ \\
10 & Gammaproteobacteria (1) & Pseudoalteromonadaceae (1) \\
11 & Proteobacteria (0.36) & \\
12 & Alphaproteobacteria (1) & Rhodospirillaceae $(0.8)$ \\
13 & Alphaproteobacteria (0.91) & Rhodospirillaceae $(0.7)$ \\
\hline
\end{tabular}

the shallow seep field Coal Oil Point in California $(<70 \mathrm{~m})$. Here about half of the methane is directly emitted to the atmosphere via bursting bubbles and the other half is injected in the water (Clark et al., 2000), some fraction of which also escapes to the atmosphere. In this study, we focus on the dissolved methane fraction that remains in the ocean and is available for microbial oxidation.

\subsection{Distribution of methane in summer and winter}

Our highest dissolved methane concentrations, measured in the bottom water during the summer survey, reach magnitudes similar to those observed at other shallow seep sites (Table 2). Our highest value of $1628 \mathrm{nM}$ is comparable to measurements downfield of the Coal Oil Point seep field (up to $1900 \mathrm{nM}$; Mau et al., 2012), although orders of magnitude less than measurements in the immediate vicinity of the bubble plumes (Clark et al., 2003). Our highest value is higher than methane concentrations reported for seep locations in the Tommeliten, North Sea (268 nM; Schneider von Deimling et al., 2011), and offshore Svalbard, west of Prins Karls Forland (524 nM; Gentz et al., 2013).

Even though gas bubbles were observed at the sea surface during the summer survey, the dissolved methane appears trapped beneath the seasonal thermocline (Fig. 4a). This ob- 

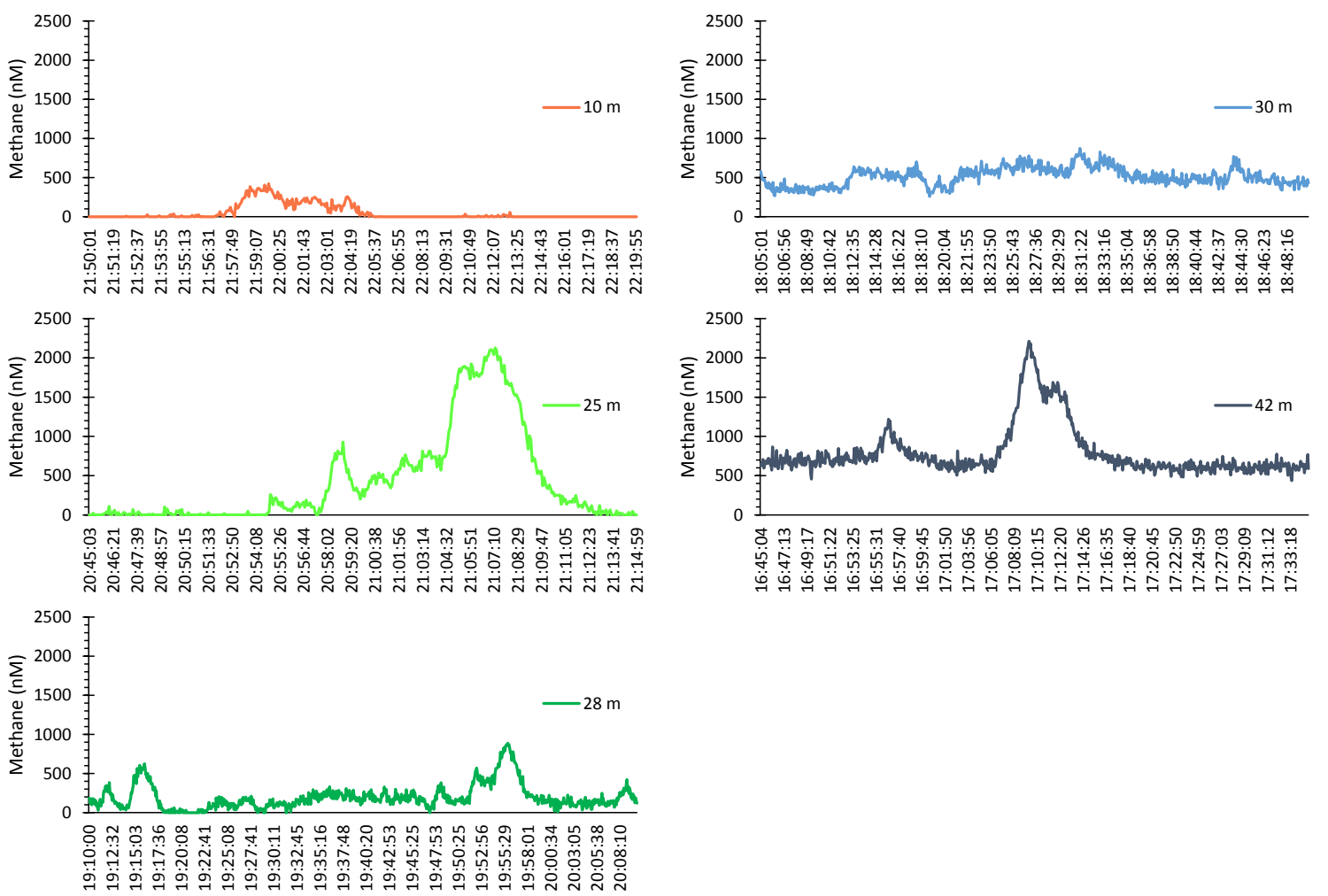

Figure 5. Methane concentrations recorded by UWMS on 21 July 2013 in the vicinity of flare cluster 1 (Fig. 2c) at different water depths. The detection limit of the instrument is $16 \mathrm{nM}$, and all measurements below this value are recorded as 0 . Apart from temporal and spatial elevations most likely due to bubble streams, the background value is elevated throughout the recording time in 30 and $42 \mathrm{~m}$ water depth.

Table 2. Comparison of highest methane concentrations, methane oxidation rates, and sea-air fluxes from different locations.

\begin{tabular}{|c|c|c|c|c|}
\hline Location & $\begin{array}{r}\text { Methane } \\
\text { concentration } \\
\text { up to } \mathrm{nM}\end{array}$ & $\begin{array}{l}\text { MOx rate } \\
\mathrm{nM} \mathrm{day}^{-1}\end{array}$ & $\begin{array}{r}\text { SAF } \\
\mathrm{nmol} \mathrm{m}^{-2} \mathrm{~s}^{-1}\end{array}$ & Reference \\
\hline \multicolumn{5}{|l|}{ Seep sites } \\
\hline Central North Sea & 1628 & $0.04-840$ & $0.02-8.3$ & this study \\
\hline Coal Oil Point, Santa Barbara Basin & 1900 & $0.02-30$ & 1.8 & Mau et al. (2012); Pack et al. (2011) \\
\hline Tommeliten, North Sea & 268 & & $10.8^{*}$ & Schneider von Deimling et al. (2011) \\
\hline West of Prins Karls Forland, Svalbard & 524 & up to 0.8 & & Gentz et al. (2013) \\
\hline Eel River basin & 300 & $0.002-0.8$ & & Valentine et al. (2001) \\
\hline \multicolumn{5}{|l|}{ Deepwater Horizon event } \\
\hline Gulf of Mexico & 180000 & up to 820 & & Valentine et al. (2010) \\
\hline Gulf of Mexico & 1000000 & up to 5900 & & Crespo-Medina et al. (2014) \\
\hline \multicolumn{5}{|l|}{ Overall areas } \\
\hline Baltic Sea & 38 & & $0.008-0.2$ & Gülzow et al. (2013) \\
\hline Southern Bight of the North Sea & 372 & $0.0002-0.3$ & $0.07-7$ & Scranton and McShane (1991) \\
\hline General European shelf estimate & 21 & & $0.11-0.24$ & Bange (2006) \\
\hline \multicolumn{5}{|l|}{ Lakes } \\
\hline Floodplain lake in southeastern Australia & 50000 & & $8.3-2700$ & Ford et al. (2002) \\
\hline Polyhumic lake in southern Finland & 150000 & $30-14400$ & $0.5-695$ & Kankaala et al. (2007) \\
\hline The subtropical Lake Kinneret in Israel & 450000 & & & Eckert and Conrad (2007) \\
\hline Freshwater reservoirs in India & 156000 & & & Narvenkar et al. (2013) \\
\hline
\end{tabular}

* Direct transport via bubbles. 

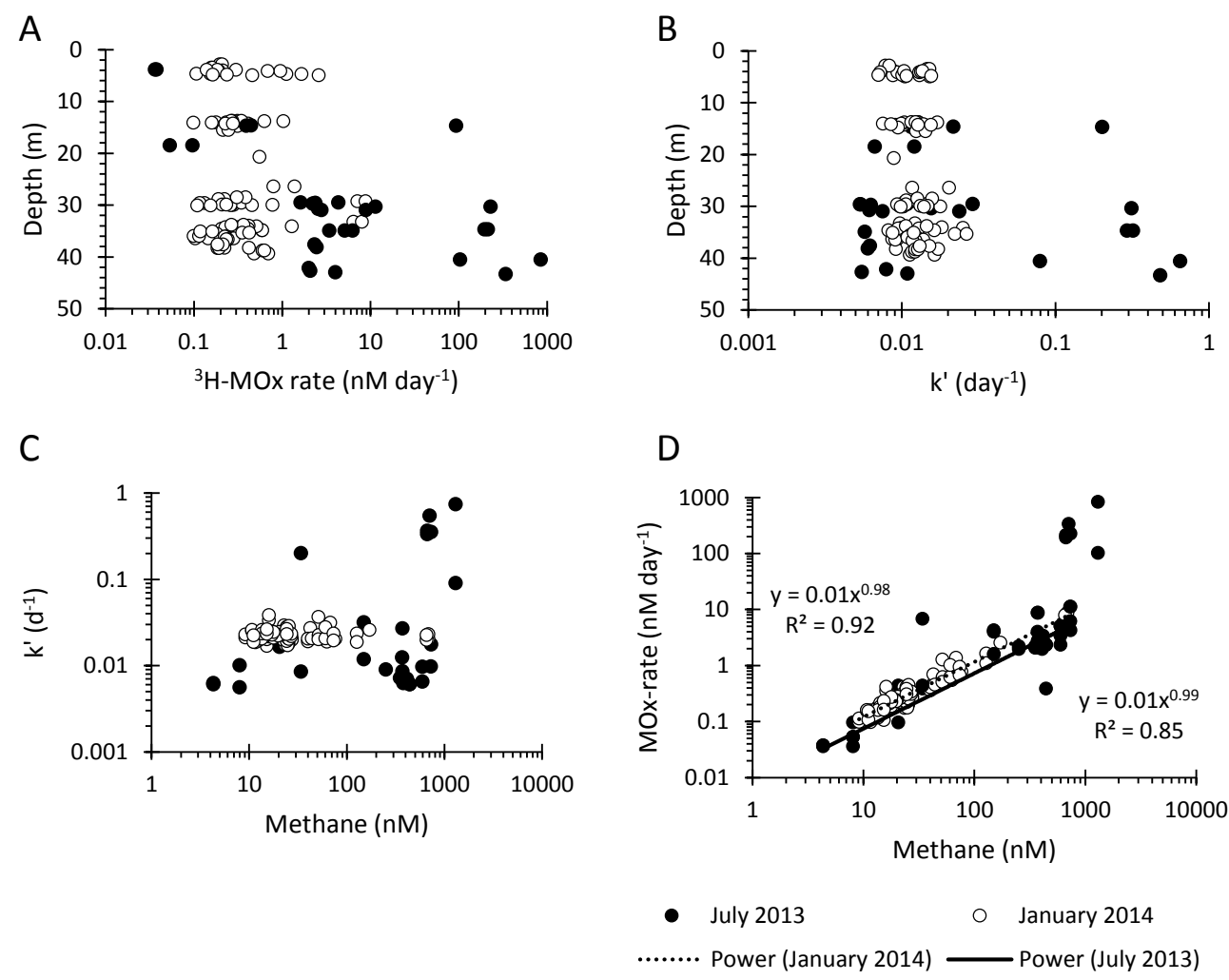

Figure 6. Methane oxidation rates versus water depth measured with ${ }^{3} \mathrm{H}$-methane in July 2013 and in January 2014 (a). (b) The first-order rate constant $k^{\prime}$ of summer and winter samples indicating the relative activity of the water. (c) $k^{\prime}$ versus methane concentration illustrate similar $k^{\prime}$ values over a wide range of methane concentration. (d) Methane oxidation rates versus methane concentrations shows for most of the data a first-order function: $\mathrm{MOx}=0.01\left[\mathrm{CH}_{4}\right]^{1}$ (function with $R^{2}$ of 0.92 derived from winter data and with $R^{2}$ of 0.85 from summer data).

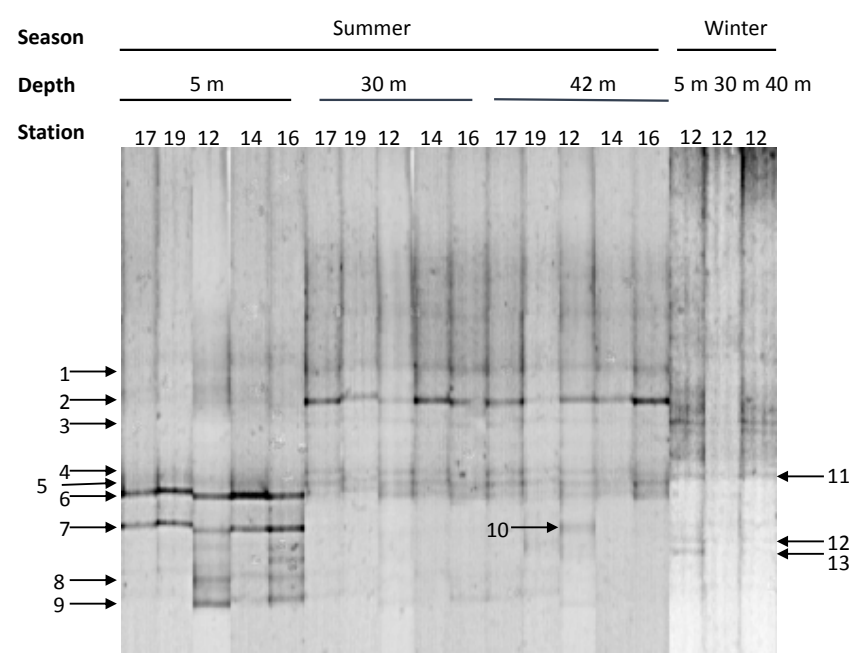

Figure 7. DGGE profile of $16 \mathrm{~S}$ rRNA gene fragments of samples from different depth and stations in the central North Sea. Numbers on the lines indicate excised and successfully sequenced DGGE bands, whose phylogenetic assignment is listed in Table 1. servation is similar to those at the Tommeliten site, where the dissolved methane plume was restricted beneath the seasonal thermocline (Schneider von Deimling et al., 2011) although gas flares were imaged to rise within $10 \mathrm{~m}$ of the sea surface. Elevated methane concentrations at other vent sites have also been reported beneath a thermocline or halocline that hamper further ascent of dissolved methane to the mixed layer. The dissolved methane plume originating from the $245 \mathrm{~m}$ deep seeps offshore Prins Karls Forland was confined to water depths beneath a local halocline (Gentz et al., 2013). In the Baltic Sea, summer stratification also leads to accumulation of methane below the thermocline (Gülzow et al., 2013). At all these sites, an enhanced release of methane to the atmosphere is thought to occur upon erosion of stratification. In contrast, the dissolved methane plume originating from seeps situated between 5 and $70 \mathrm{~m}$ at the Coal Oil Point is dispersed within the mixed layer above the thermocline (Mau et al., 2012), and as such it is not controlled by seasonal stratification patterns.

Trapping and accumulation of dissolved methane beneath a thermocline also is well documented in lakes and freshwater reservoirs, where thermal stratification separates methane-poor surface water from the methane-rich, but 
anoxic, bottom water in, e.g., a shallow floodplain lake in southeastern Australia (Ford et al., 2002), in a polyhumic lake in southern Finland (Kankaala et al., 2007), in the subtropical Lake Kinneret in Israel (Eckert and Conrad, 2007), and in eight freshwater reservoirs in India (Narvenkar et al., 2013). In these locations, the accumulated methane is released to the atmosphere at the onset of water column mixing in response to enhanced wind forcing and lower temperatures.

Our results show that in a seasonal stratified system, methane accumulation does not occur in winter, when the water column is well mixed (Fig. 4b). Methane concentrations were found to deviate only due to bubble ascent and were otherwise low and constant throughout the water. The median winter concentration of $22 \mathrm{nM}$ is similar to the background values of $20 \mathrm{nM}$ reported by Grunwald et al. (2009) for the German Bight but is elevated relative to water originating from the Atlantic Ocean, which carries 2.5-3.5 nM of methane (Rehder et al., 1998) and to the methane background concentrations of $<5 \mathrm{nM}$ at Tommeliten (Niemann et al., 2005; Schneider von Deimling et al., 2011).

The observed difference between summer and winter dissolved methane concentrations also may be due to changes in seepage rate. The visual observation of gas bubbles during the summer, the sub-bottom profiler recording of gas plumes in the water column in August 2002 by Schroot et al. (2005), and our acoustic records of gas flares in the winter (Fig. 2b) indicate that seepage occurred during both seasons. Notwithstanding these observations, we recognize that we have insufficient temporal data coverage and that bubble release frequency, bubble size, and initial methane content could vary between our surveys, causing the difference in overall methane concentrations (Greinert and McGinnis, 2009; Leifer and Clark, 2001; McGinnis et al., 2006). However, even when a change in seepage regimes could affect the overall methane concentration, it would not explain the difference in the shape of the methane profiles observed between summer and winter surveys.

Discrete sampling bias and current variability also explain some fraction of the difference observed between summer and winter dissolved methane concentrations. The currents had a strong westward component during summer sampling with small north/south deviation throughout the water column (Supplement 2), and thus the easternmost profiles are likely to be less influenced from direct bubble seepage (Fig. 4a). However, the profiles still show elevated methane concentration in the bottom water and lower concentrations in the shallow samples, consistent with methane trapping below the seasonal thermocline. We considered whether the low observed concentrations during winter may be due to the fact that during this survey we only partially sampled isolated plumes. Although the east-west transect directly crosses the cluster 1 flares (Fig. 2) and was oriented in direction of the tidal movement in that area, the stronger northward component of the current in winter (Supplements 2 and 3) displaced methane plumes more rapidly than in summer. The elevated methane concentrations at the central seep site and along the western transect (although with much lower methane concentrations) suggest that we indeed sampled methane plumes (Fig. 4b). We note that the horizontal concentration gradients in surface water were 0.01 to $0.02 \mathrm{nM} \mathrm{m}^{-1}$ during summer and winter, respectively. As a first-order approximation we took the highest concentration measured (39 in summer and $73 \mathrm{nM}$ in winter) and a general current speed of $0.2 \mathrm{~m} \mathrm{~s}^{-1}$ to estimate a plume size of $\sim 4 \mathrm{~km}$ in diameter that would take $\sim 5 \mathrm{~h}$ to cross our sampling transect. Since we always sampled five stations in $\sim 3 \mathrm{~h}$ for the eastern or western segments of the transect, it seems rather unlikely that we completely missed a methane plume.

To summarize, even when methane concentrations may appear biased by discrete sampling, current differences, and seepage rate, our data analyses suggest that the seasonal differences are real. Even if the total magnitudes may be questioned, we are confident that the methane distribution pattern is the result of seasonal stratification.

\subsection{Interpreting methane oxidation rate data}

Measured MOx rates at our study site (Fig. 6a) lie at the upper end of MOx rates previously reported at sites elsewhere, which span over 6 orders of magnitude from 0.001 to $1000 \mathrm{nM}_{\text {day }}{ }^{-1}$ (Table 2, Supplement 7 by Mau et al., 2013). The rates measured in deep water samples during summer (median 3.9, up to $840 \mathrm{nM}_{\text {day }}{ }^{-1}$ ) equal those observed in the Gulf of Mexico after the Deepwater Horizon event (median $10 \mathrm{nM} \mathrm{d}^{-1}$, up to $820 \mathrm{nM}_{\text {day }}{ }^{-1}$ ) (Valentine et al., 2010). Even in wintertime, the estimated rates are high in comparison to those measured in the Eel River basin, an area of documented gas hydrate dissociation (Valentine et al., 2001) and match rates downcurrent of the Coal Oil Point seep field in the Santa Barbara Basin (Mau et al., 2012; Pack et al., 2011).

In spite of the reported high MOx values, our data reveal an overall low activity of methane oxidizing microorganisms based on the values obtained for the rate constant $k^{\prime}$, which provides an indication of the relative activity in a water sample (Koschel, 1980). This is a first-order constant if the reaction is solely dependent on the methane concentration and biomass does not increase during incubation. Our experiments yielded similar $k^{\prime}$ values over a wide range of methane concentrations, from 4 to $728 \mathrm{nM}$ (Fig. 6c). Furthermore, the good correlation between MOx rates and methane concentration (Fig. 6d) indicate that the biomass did not increase during incubation, thus validating our inferences on microbial activity based on $k^{\prime}$ values. Based on 116 (out of 123) measurements we calculate an average value for $k^{\prime}$ of 0.01 day $^{-1}$, i.e., a turnover time of 100 days (Fig. 6b). This value matches the value $k^{\prime}$ derived from our time series incubation results $\left(0.01 \mathrm{day}^{-1}, n=4\right)$, which show that only $5-6 \%$ of the added ${ }^{3} \mathrm{H}$-methane tracer was consumed by microbial 
activity after 4 incubation days (Supplement 8 ). The time series show a linear increase of tracer oxidation and the function derived from Fig. $6 \mathrm{~d}$ that yield a first-order relationship between methane oxidation rates and methane concentration with $k^{\prime}=0.01$. If we use the average $k^{\prime}$ and methane concentrations that span $4-728 \mathrm{nM}$, the resulting oxidation rates (Eq. 1) range between 0.04 and $7.3 \mathrm{nM}_{\text {day }^{-1}}$. Thus relatively high MOx rates here reflect primarily high methane concentrations and must not be taken as indication of a high microbial turnover.

We note that seven data points collected in summer near flare cluster 1 (stations 12 and 13) had $k^{\prime}$ values ranging from 0.08 to $0.64 \mathrm{day}^{-1}$, significantly higher than the rest of the measurements. These high values multiplied with high corresponding methane concentrations gave the highest MOx values measured during this study. These elevated $k^{\prime}$ values may indicate an increase in biomass and/or an increase in activity of the methane oxidizing community in the water sample during incubation.

The general low activity of methane oxidizing microorganisms is further supported by molecular analysis of filtered matter from seawater. Consistently, DGGE and pmoA analysis did not reveal the presence of any known methanotrophic bacteria or $p m o A$ genes. Either methanotrophs were only present in low numbers and/or poorly matched to the used PCR primers and, thus, were not detected (Hansman, 2008). We also note that although no canonical methanotrophs were detectable in shallow marine waters $(<200 \mathrm{~m})$ in the Pacific, Atlantic, and the Gulf of Mexico, further analyses of these samples revealed sequences closely related to those coding for methane monooxygenase (Elsaied et al., 2004; Tavormina et al., 2008, 2013; Valentine, 2011; Wasmund et al., 2009), an enzymatic hallmark of aerobic methanotrophs. We recognize that not having detected methanotrophs in our samples does not preclude their presence in the water column.

Even though during summer stratification methane is trapped beneath the seasonal thermocline, the resulting higher methane concentrations do not appear to enhance the activity of methane oxidation microbes. The residence time of central North Sea water is about 1.5-2 years (Prandle, 1984; Ursin and Andersen, 1978) and thermal stratification prevails for 4 months, which may provide sufficient time to establish a methanotrophic community. However, microbial turnover times in bottom water samples are consistently low and we were not able to identify methanotrophic organisms in the water column. Doubling times of planktonic marine methanotrophs are not known to the authors, but if we assume a doubling time of $\sim 10 \mathrm{~h}$ as known from cultured methanotrophs (Baani and Liesack, 2008; Khadem et al., 2010) or a doubling time of 3.5 days estimated after the Deep Water Horizon incident in the Gulf of Mexico (Kessler et al., 2011), a methanotrophic community could potentially develop in the central North Sea during the 4 months where stratification leads to enhanced methane content in the bottom water. Even if the doubling time of methanotrophs in the field was longer than in culture as nutrients and substrates can be limiting, the residence time of the water would permit growth. Possible limitations may be a lack of essential trace elements or that the methane oxidizing microorganisms are facultative methanotrophs (Tavormina et al., 2013), i.e., not necessarily depending on methane.

In summary, even though total MOx rates are necessary to constrain overall methane budgets and carbon cycles, to better characterize microbial activity among different ecosystems it is necessary to also report data on the microbial turnover rates at each site. The low turnover rates measured here are consistent with molecular analyses that failed to identify methanotrophic bacteria or $p m o A$ genes. Enhanced methane concentrations do not appear to foster higher turnover rates.

\subsection{Methane transport in the North Sea is faster than oxidation}

When methane enters the water column, either directly from the seep or by dissolution/gas exchange from ascending bubbles, it is transported by ocean currents and spreads by horizontal and vertical eddy diffusion. Methane oxidizing microorganisms can consume dissolved methane in the water column, and methane will be transferred into the atmosphere if its concentration in the mixed layer is higher than saturation.

As a first-order evaluation of the relative importance of these transport and loss processes, we estimated the advective transport, the horizontal and vertical eddy diffusion, seaair flux, and integrated the MOx rates (see methods and Mau et al., 2012). Summer fluxes for the bottom (30-43 m) and surface waters $(0-30 \mathrm{~m})$ were estimated using data collected in July 2013, and winter fluxes were derived for the entire unstratified water column ( $0-42 \mathrm{~m})$ using data from January 2014. All fluxes were estimated in units of $n m o l m^{-2} \mathrm{~s}^{-1}$. These flux estimates may vary by up to 1 order of magnitude due to precision of the measurements, the parameterization of the gas transfer velocity, and assumed diffusion coefficients (see methods for more detail).

The results shown in Fig. 8 revealed that in both summer and winter seasons, horizontal advection and eddy diffusion are the dominant processes transporting and diluting the emitted methane. The loss processes, i.e., sea-air flux and microbial oxidation, are more than 4 orders of magnitude lower than physical horizontal transport processes.

Vertical mixing due to internal waves resulting from proximity to the elevation of the Dogger Bank cannot be ruled out. Estimates of $\kappa_{z}$ for the shelf break range on the order of 0.5$0.7 \times 10^{-4} \mathrm{~m}^{2} \mathrm{~s}^{-1}$ (Palmer et al., 2008). Our vertical fluxes based on $\kappa_{z}=10^{-4} \mathrm{~m}^{2} \mathrm{~s}^{-1}$ thus include the enhanced mixing by internal waves that support increased transport across the seasonal thermocline.

Not surprisingly, the sea-air flux removes more methane from the water column during winter due to increased wind 

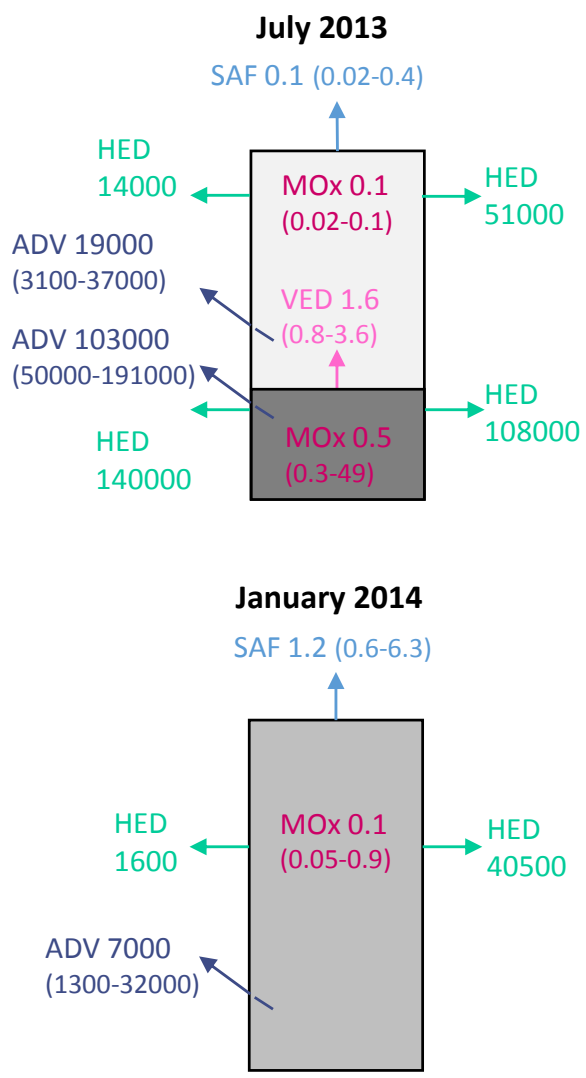

$$
\begin{aligned}
& \text { SAF - sea-air flux } \\
& \text { MOx - methane oxidation rate } \\
& \text { VED - vertical eddy diffusion } \\
& \text { HED - horizontal eddy diffusion } \\
& \text { ADV - advection } \\
& \text { Median of estimates (range of estimates) }
\end{aligned}
$$

Figure 8. Sketch of transport and loss terms estimated for the study area in $\mathrm{nmol} \mathrm{m} \mathrm{m}^{-2} \mathrm{~s}^{-1}$.

speed and storm sparging (Shakhova et al., 2013). More unexpectedly, our flux estimates revealed that within our study area the amount of methane that is transported in summer via vertical diffusion into the surface water is of similar magnitude to the loss by oxidation in the bottom water, even water stratification leads to enhanced methane concentrations at depth. When lower wind speeds prevail, methane oxidation was estimated to be of similar magnitude as the gas transfer to the atmosphere. However, our estimates do not include potential transport to the atmosphere as bottom water reached topographic highs such as the Dogger Bank or areas with no stratification.

Our findings are similar to those reported by Scranton and McShane (1991) for the Southern Bight of the North Sea. They found methane oxidation $\left(0.00023-0.3 \mathrm{nM} \mathrm{day}^{-1}\right)$ and methane loss to the atmosphere $\left(0.00026-7.5 \mathrm{nM} \mathrm{day}^{-1}\right)$ of a similar magnitude, but the latter increased during periods of high wind speed. Estimates for the shallow Coal Oil Point methane plume in the Santa Barbara Basin (Mau et al., 2012) show that at this location $0.05 \mathrm{~mol} \mathrm{day}^{-1}$ is oxidized in the surface water and $0.03 \mathrm{~mol} \mathrm{day}^{-1}$ is transferred to the atmosphere, i.e., both methane loss processes are of similar magnitude.

\section{Conclusions}

1. Observations at a shallow gas seep site in the central North Sea document elevated methane concentrations below the thermocline during summer stratification. In contrast, regional background methane concentrations were observed throughout the water column in the winter, when the water column is well mixed.

2. At our study site, physical transport processes always out-compete microbial methane oxidation. Horizontal advection and diffusion of methane are consistently higher than vertical transport, even within order of magnitude uncertainties. During periods of high wind speed (fall and winter), more methane reaches the atmosphere than is oxidized in the water; in summer the loss to the atmosphere and the oxidation terms are of similar magnitude.

3. We show that MOx rates alone cannot be used to characterize the ecosystem microbial activity, as these values are scaled to the methane concentration. We instead propose to include interpretation of $k^{\prime}$ values as an indicator of microbial activity. Averaged $k^{\prime}$ values generate a more realistic parameter than values based solely on replicate samples as further documented by our workintensive time series incubations.

4. Our results demonstrate that trapping of methane below a seasonal thermocline does not necessarily lead to enhance microbial oxidation. Further research is needed to elucidate why stratification over a summer season of 4 months does not enhance methanotrophy enough to significantly hamper methane release to the atmosphere upon water column mixing.

\section{The Supplement related to this article is available online at doi:10.5194/bg-12-5261-2015-supplement.}

Author contributions. S. M. designed the study, measured methane concentrations and methane oxidation rates, calculated the fluxes, and wrote the manuscript. T. G., R. M., and M. S. deployed the UWMS and post-processed the data; J.-H. K., M. R., H. S., and P. W. collected and post-processed hydroacoustic data; M. T. interpreted the methane oxidation rate data and edited the manuscript; E. H. implemented and interpreted molecular analyses. 
Acknowledgements. We are indebted to the captain, crew, and scientific research party of the research vessel Heincke (cruise HE406 and HE413) and especially to the applicants of RV Heincke cruises HE 406 and HE413 and organizers Sabine Kasten and Gerhard Bohrmann. We would like to thank Sven Klüber, Eva Kirschenmann, and Monika Wiebe for their help collecting and analyzing samples on board and in the laboratory. We are grateful to Tessa Clemes from Alfred Wegener Institute Helmholtz Centre for Polar and Marine Research (Bremerhaven, Germany), who implemented the microbial analyses. We like to thank Antje Boetius, Gunter Wegener, and Mirja Meiners from the Max Planck Institute for Marine Microbiology (Bremen, Germany) for providing scientific equipment and laboratory support for oxidation rate measurements. Marta Torres acknowledges support through a fellowship from the Hanse-Wissenschaftskolleg. This work is part of the DFG project "Limitations of Marine Methane Oxidation" (MA 3961/2-1).

The article processing charges for this open-access publication were covered by the University of Bremen.

Edited by: T. Treude

\section{References}

Baani, M. and Liesack, W.: Two isozymes of particlate methane monooxygenase with different methane oxidation kinetics are found in Methylocystis sp. strain SC2, PNAS, 105, 1020310208, 2008.

Bange, H. W.: Nitrous oxide and methane in European coastal waters, Estuar. Coast. Shelf S., 70, 361-374, 2006.

Bange, H. W., Bartell, U. H., Rapsomanikis, S., and Andreae, M. O.: Methane in the Baltic and North Seas and a reassessment of the marine emissions of methane, Global Biogeochem. Cy., 8, 465-480, 1994.

Bell, R. J., Short, R. T., Van Amerom, F. H. W., and Byrne, R. H.: Calibration of an in situ membrane inlet mass spectrometer for measurements of dissolved gases and volatile organics in seawater, Environ. Sci. Technol., 41, 8123-8128, 2007.

Berner, R. A.: Biogeochemical cycles of carbon and sulfur and their effect on atmospheric oxygen over Phanerozoic time, Palaeogeogr. Palaeocl., 73, 97-122, 1989.

Boetius, A., Ravenschlag, K., Schubert, C. J., Rickert, D., Widdel, F., Gieskes, A., Amann, R., Jørgensen, B. B., Witte, U., and Pfannkuche, O.: A marine microbial consortium apparently mediating anaerobic oxidation of methane, Nature, 407, 623-626, 2000.

Boles, J. R., Clark, J. F., Leifer, I., and Washburn, L.: Temporal variation in natural methane seep rate due to tides, Coal Oil Point area, California, J. Geophys. Res., 106, 27077-27086, 2001.

Cicerone, R. J. and Oremland, R. S.: Biochemical aspects of atmospheric methane, Global Biogeochem. Cy., 2, 299-327, 1988.

Clark, J. F., Leifer, I., Washburn, L., and Luyendyk, B. P.: Compositional changes in natural gas bubble plumes: observations from the Coal Oil Point marine hydrocarbon seep field, Geol.Mar. Lett., 23, 187-193, 2003.
Denman, K. L. and Gargett, A. E.: Time and space scales of vertical mixing and advection of phytoplankton in the upper ocean, Limnol. Oceanogr., 28, 801-815, 1983.

Eckert, W. and Conrad, R.: Sulfide and methane evolution in the hypolimnion of a subtropical lake: a three-year study, Biogeochemistry, 82, 67-76, 2007.

Elsaied, H. E., Hayashi, T., and Naganuma, T.: Molecular analysis of deep-sea hydrothermal vent aerobic methanotrophs by targeting genes of 16S rRNA and particulatemethane monooxygenase, Mar. Biotechnol., 6, 503-509, 2004.

Etiope, G., Lassey, K. R., Klusman, R. W., and Boschi, E.: Reappraisal of the fossil methane budget and related emission from geologic sources, Geophys. Res. Lett., 35, L09307, doi:10.1029/2008GL033623, 2008.

Ford, P. W., Boon, P. I., and Lee, K.: Methane and oxygen dynamics in a shallow floodplain lake: the significance of period stratification, Hydrobiologia, 485, 97-110, 2002.

Gentz, T. and Schlüter, M.: Underwater cryotrap-membrane inlet system (CT-MIS) for improved in situ analysis of gases, Limnol. Oceanogr., 10, 317-328, 2012.

Gentz, T., Damm, E., Schneider von Deimling, J., Mau, S., McGinnis, D. F., and Schlüter, M.: A water column study of methane around gas flares located at the West Spitsbergen continental margin, Cont. Shelf Res., 72, 107-118, doi:10.1016/j.csr.2013.07.013, 2013. 2013.

Gerdes, B., Brinkmeyer, R., Dieckmann, G., and Helmke, E.: Influence of crude oil on changes of bacterial communities in Arctic sea-ice, FEMS Microbiol. Ecol., 53, 129-139, 2005.

Greinert, J. and McGinnis, D. F.: Single bubble dissolution model The graphical user interface SiBu-GUI, Environ. Model. Softw., 24, 1012-1013, 2009.

Grunwald, M., Dellwig, O., Beck, M., Dippner, J. W., Freund, J. A., Kohlmeier, C., Schnetger, B., and Brumsack, H.-J.: Methane in the southern North Sea: Sources, spatial distribution and budgets, Estuar. Coast. Shelf S., 81, 445-456, 2009.

Gülzow, W., Rehder, G., Schneider v. Deimling, J., Seifert, T., and Tóth, Z.: One year of continuous measurements constraining methane emissions from the Baltic Sea to the atmosphere using a ship of opportunity, Biogeosciences, 10, 81-99, doi:10.5194/bg10-81-2013, 2013.

Hansman, R. L.: Microbial Metabolism in the Deep Ocean, Ph.D. thesis, Oceanography, University of California San Diego, 158 pp., 2008.

Holt, J. and Umlauf, L.: Modelling the tidal mixing fronts and seasonal stratification of the Northwest European Continental shelf, Cont. Shelf Res., 28, 887-903, 2008.

Howarth, M. J.: North Sea Circulation, in: Encyclopedia of Ocean Sciences, edited by: Steele, J. H., Academic Press, Oxford, 1912-1921, 2001.

IPCC: Climate Change 2013 - The Physical Science Basis - Contribution of Working Group I to the Fifth Assessment Report of the Intergovernmental Panel on Climate Change, Cambridge University Press, Cambridge, 2013.

Jørgensen, B. B. and Kasten, S.: Sulfur Cycling and Methane Oxidation, in: Marine Geochemistry, edited by: Schulz, H. D. and Zabel, M., Springer, Berlin Heidelberg, 271-309, 2006.

Kankaala, P., Taipale, S., Nykänen, H., and Jones, R. I.: Oxidation, efflux, and isotopic fractionation of methane during autum- 
nal turnover in a polyhumic, boreal lake, J. Geophys. Res., 112, G02003, doi:10.1029/2006JG000336, 2007.

Kessler, J. D., Valentine, D. L., Redmond, M. C., Du, M., Chan, E. C., Mendes, S. D., Quiroz, E. W., Villanueva, C. J., Shusta, S. S., Werra, L. M., Yvon-Lewis, S. A., and Weber, T. C.: A persistent oxygen anomaly reveals the fate of spilled methane in the deep Gulf of Mexico, Science, 331, 312-315, 2011.

Khadem, A. F., Pol, A., Jetten, M. S. M., and Op den Camp, H. J. M.: Nitrogen fixation by the verrucomicrobial methanotroph "Methylacidiphilum fumariolicum" SolV, Microbiology, 156, 1052-1059, 2010.

Killops, S. D. and Killops, V. J.: An Introduction to Organic Geochemistry, Longman, Essex, United Kingdom, 1993.

King, G. M.: Ecological aspects of methane oxidation, a key determinant of global methane dynamics, Adv. Microb. Ecol., 12, 432-468, 1992.

Koschel, R.: Untersuchungen zur Phosphataffinitat des Planktons in der euphotischen Zone von Seen, Limnologica, 12, 141-145, 1980.

Kröncke, I. and Knust, R.: The Dogger Bank: a special ecological region in the central North Sea, Helgoländer Meeresunters., 49, 335-353, 1995.

Largier, J. L.: Considerations in estimating larval dispersal distances from oceanographic data, Ecol. Appl., 13, 71-89, 2003.

Leifer, I. and Clark, J.: Modeling trace gases in hydrocarbon seep bubbles. Application to marine hydrocarbon seeps in the Santa Barbara Channel, Russ. Geol. Geophys., 43, 613-621, 2001.

Magen, C., Lapham, L. L., Pohlman, J. W., Marshall, K., Bosman, S., Casso, M., and Chanton, J. P.: A simple headspace equilibration method for measuring dissolved methane, Limnol. Oceanogr. Methods, 12, 637-650, 2014.

Mau, S., Valentine, D. L., Clark, J. F., Reed, J., Camilli, R., and Washburn, L.: Dissolved methane distributions and air-sea flux in the plume of a massive seep field, Coal Oil Point, California, Geophys. Res. Lett., 34, L22603, doi:10.1029/2007GL031344, 2007.

Mau, S., Heintz, M. B., and Valentine, D. L.: Quantification of $\mathrm{CH}_{4}$ loss and transport in dissolved plumes of the Santa Barbara Channel, California, Cont. Shelf Res., 32, 110-120, 2012.

Mau, S., Blees, J., Helmke, E., Niemann, H., and Damm, E.: Vertical distribution of methane oxidation and methanotrophic response to elevated methane concentrations in stratified waters of the Arctic fjord Storfjorden (Svalbard, Norway), Biogeosciences, 10, 6267-6278, doi:10.5194/bg-10-6267-2013, 2013.

McDonald, I. R. and Murrell, J. C.: The particulate methane monooxygenase gene pmoA and its use as a functional gene probe for methanotrophs, FEMS Microbiol. Lett., 156, 205-210, 1997.

McDonald, I. R., Bodrossy, L., Chen, Y., and Murrell, J. C.: Molecular ecology techniques for the study of aerobic methanotrophs, Appl. Environ. Microb., 74, 1305-1315, 2008.

McGinnis, D. F., Greinert, J., Artemov, Y., Beaubien, S. E., and Wuest, A.: Fate of rising methane bubbles in stratified waters: How much methane reaches the atmosphere?, J. Geophys. Res., 111, 1-15, 2006.

McGillis, W., R., Edson, J., B., Ware, J., D., Dacey, J., W. H., Hare, J., E., Fairall, C., W., and Wanninkhof, R.: Carbon dioxide flux techniques performed during GasEx-98, Mar. Chem., 75, 267280, 2001.
Muyzer, G., de Waal, E., and Uitterlinden, A.: Profiling of complex microbial populations by denaturing gradient gel electrophoresis analysis of polymerase chain reaction-amplified genes coding for 16S rRNA, Appl. Environ. Microbiol., 59, 695-700, 1993.

Narvenkar, G., Naqvi, S. W. A., Kurian, S., Shenoy, D. M., Pratihary, A. K., Naik, H., Patil, S., Sarkar, A., and Gauns, M.: Dissolved methane in Indian freshwater reservoirs, Environ. Monit. Assess., 185, 6989-6999, 2013.

Niemann, H., Elvert, M., Hovland, M., Orcutt, B., Judd, A., Suck, I., Gutt, J., Joye, S., Damm, E., Finster, K., and Boetius, A.: Methane emission and consumption at a North Sea gas seep (Tommeliten area), Biogeosciences, 2, 335-351, doi:10.5194/bg2-335-2005, 2005.

Niewöhner, C., Hensen, C., Kasten, S., Zabel, M., and Schulz, H. D.: Deep sulfate reduction completely mediated by anaerobic methane oxidation in sediments of the upwelling area off Namibia, Geochim. Cosmochim. Ac., 62, 455-464, 1998.

Osborn, T. R.: Estimates of the local rate of diffusion from dissipation measurements, J. Phys. Oceanogr., 10, 83-89, 1980.

Otto, L., Zimmermann, J. T. F., Furnes, G. K., Mork, M., Saetre, R., and Becker, G.: Review of the physical oceanography of the North Sea, Neth. J. Sea Res., 26, 161-238, 1990.

Pack, M. A., Heintz, M. B., Reeburgh, W. S., Trumbore, S. E., Valentine, D. L., Xu, X., and Druffel, E. R. M.: A method for measuring methane oxidation rates using low-levels of ${ }^{14} \mathrm{C}$ labeled methane and accelerator mass spectrometry, Limnol. Oceanogr., 9, 245-260, 2011.

Palmer, M. R., Rippeth, T. P., and Simpson, J. H.: An investigation of internal mixing in a seasonally stratified shelf sea, J. Geophys. Res., 113, 1-14, 2008.

Pingree, R. D. and Griffiths, D. K.: Tidal Fronts on the Shelf Seas Around the British Isles, J. Geophys. Res., 83, 4615-4622, 1978.

Prandle, D.: A modelling study of the mixing of ${ }^{137} \mathrm{Cs}$ in the seas of the European continental shelf, Philos. T. Roy. Soc. A, 310, 407-436, 1984.

Pruesse, E., Peplies, J., and Glöckner, F. O.: SINA: accurate high-throughput multiple sequence alignment of ribosomal RNA genes, Bioinformatics, 28, 1823-1829, 2012.

Reeburgh, W. S., Ward, B. B., Whalen, S. C., Sandbeck, K. A., Kilpatrick, K. A., and Kerkhof, L. J.: Black Sea methane geochemistry, Deep-Sea Res., 38, S1189-S1210, 1991.

Rehder, G., Keir, R. S., Suess, E., and Pohlmann, T.: The multiple sources and patterns of methane in North Sea waters, Aquat Geochem., 4, 403-427, 1998.

Roberts, P. J. W. and Webster, D. R.: Turbulent Diffusion. In: Environmental Fluid Mechanics-Theories and Application, edited by: Shen, H., Cheng, A., Wang, K.-H., Teng, M. H., and Liu, C., Amer. Soc. Civil Eng. Press, Reston, Virginia, 2002.

Schlüter, M. and Gentz, T.: Application of membrane inlet mas spectrometry for online and in situ analysis of methane in aquatic environments, J. Am. Soc. Mass Spectrom., 19, 1395-1402, 2008.

Schneider von Deimling, J., Rehder, G., Greinert, J., McGinnis, D. F., Boetius, A., and Linke, P.: Quantification of seep-related methane gas emissions at Tommeliten, North Sea, Cont. Shelf Res., 31, 876-878, 2011.

Schroot, B. M., Klaver, G. T., and Schuettenhelm, T. E.: Surface and subsurface expressions of gas seepage to the seabed - examples 
from the southern North Sea, Mar. Petrol. Geol., 22, 499-515, 2005.

Scranton, M. I. and McShane, K.: Methane fluxes in the southern North Sea: The role of European rivers, Cont. Shelf Res., 11, 37-52, 1991.

Shakhova, N., Semiletov, I., Leifer, I., Sergienko, V., Salyuk, A., Kosmach, D., Chernykh, D., Stubbs, C., Nicolsky, D., Tumskoy, V., and Gustafsson, Ö.: Ebullition and storm-induced methane release from the East Siberian Arctic Shelf, Nature Geosci., 7, 64-70, 2013.

Short, R. T., Fries, D. P., Kerr , M. L., Lembke, C. E., Toler, S. K., Wenner, P. G., and Byrne, R. H.: Underwater mass spectrometers for in situ chemical analysis of the hydrosphere, J. Am. Soc. Mass Spectrom., 12, 676-682, 2001.

Sündermann, J. and Pohlmann, T.: A brief analysis of North Sea physics, Oceanologia, 53, 663-689, 2011.

Sundermeyer, M. A. and Price, J. F.: Lateral mixing and the North Atlantic tracer release experiment: observations and numerical simulations of Lagrangian particles and a passive tracer, J. Geophys. Res., 103, 21481-21497, 1998.

Tavormina, P. L., Ussler III, W., and Orphan, V. J.: Planktonic and sediment-associated aerobic methanotrophs in two seep systems along the North American Margin, Appl. Environ. Microbiol., 74, 3985-3995, 2008.

Tavormina, P. L., Ussler, W., Steele, J. A., Connon, S. A., Klotz, M. G., and Orphan, V. J.: Abundance and distribution of diverse membrane-bound monooxygenase (Cu-MMO) genes within the Costa Rica oxygen minimum zone, Environ. Microbiol. Reports, 5, 414-423, 2013.

Thorpe, S. A., Green, J. A. M., Simpson, J. H., Osborn, T. R., and Nimmo Smith, W. A. M.: Boils and turbulences in a weakly stratified shallow tidal sea, J. Phys. Oceanogr., 38, 1711-1730, 2008.
Ursin, E. and Andersen, K. P.: A model of the biological effects of eutrophication in the North Sea, Rapp. P.-v. Reun. Cons. Int. Explor. Mer, 172, 366-377, 1978.

Valentine, D. L.: Emerging topics in marine methane biogeochemistry, Annu. Rev. Mar. Sci., 3, 147-171, 2011.

Valentine, D. L., Blanton, D. C., Reeburgh, W. S., and Kastner, M.: Water column methane oxidation adjacent to an area of active hydrate dissociation, Eel River Basin, Geochim. Cosmochim. Ac., 65, 2633-2640, 2001.

Valentine, D. L., Kessler, J. D., Redmond, M. C., Mendes, S. D., Heintz, M. B., Farwell, C., Hu, L., Kinnaman, F. S., Yvon-Lewis, S., Du, M., Chan, E. W., Tigreros, F. G., and Villanueva, C. J.: Propane respiration jump-starts microbial response to a deep oil spill, Science, 330, 208-211, 2010.

Wasmund, K., Kurtboke, D. I., Burns, K. A., and Bourne, D. G.: Microbial diversity in sediments associated with a shallow methane seep in the tropical Timor Sea of Australia reveals a novel aerobic methanotroph diversity, FEMS Microbiol. Ecol., 68, 142151, 2009.

Wenner, P. G., Bell, P. G., van Amerom, F. H. W., Toler, S. K., Edkins, J. E., Hall, M. L., Koehn, K., Short, R. T., and Byrne, R. H.: Environmental chemical mapping using an underwater mass spectrometer, Trac-Trend Anal. Chem., 23, 288-295, 2004.

Wiesenburg, D. A. and Guinasso, J. N. L.: Equilibrium solubilities of methane, carbon monoxide, and hydrogen in water and sea water, J. Chem. Eng. Data, 24, 356-360, 1979.

Wunsch, C. and Ferrari, R.: Vertical mixing, energy, and the general circulation of the oceans, Annu. Rev. Fluid Mech., 36, 281-314, 2004. 